\title{
PERSEPSI PELAKU UKM TERHADAP LAPORAN KEUANGAN BERDASARKAN STANDAR AKUNTANSI KEUANGAN ENTITAS TANPA AKUNTABILITAS PUBLIK (SAK ETAP)
}

\begin{abstract}
This study aims to determine the perceptions of batik SMEs "Pring Sedapur" on the preparation of financial reports based on SAK ETAP in Sidomukti Village, Plaosan District, Magetan Regency.

This study used a survey method with a quantitative approach that was conducted on 3 respondents. The technique of collecting data uses structured interviews, interviews, and document studies. and data analysis techniques use descriptive analysis techniques.

The results showed that the factors of age, education and the length of time to open a business / experience did not indicate a difference of opinion about their perceptions of the application of accounting. SMEs have made accounting records even though they are still very simple. They have not made journals, ledgers and prepared financial reports in accordance with SAK ETAP, because of limited knowledge and information on how to apply accounting in accordance with SAK ETAP.
\end{abstract}

Keywords: Perception, application of accounting, SAKETAP

\section{PENDAHULUAN}

\section{Latar Belakang}

Usaha Kecil dan Menengah (UKM) merupakan suatu kegiatan usaha kecil yang dibentuk oleh masyarakat yang pendiriannya berdasarkan inisiatif seorang perorangan. UKM memiliki perkembangan yang cukup pesat di berbagai wilayah. Di Indonesia sendiri sudah banyak sekali bermunculan UKM dengan berbagai bidang usaha dan bahkan UKM telah menjadi penyelamat dan penompang pertumbuhan ekonomi Indonesia. UKM memiliki konstribusi yang cukup besar bagi pemberdayaan ekonomi masyarakat Indonesia namun di balik keunggulannya, UKM masih memiliki beberapa kelemahan yang hingga kini masih harus diperbaiki. Kelemahan tersebut cukup bervariasi, namun disini yang memiliki dampak cukup signifikan dalam perkembangan UKM salah satunya adalah Informasi Akuntansi yang ada pada UKM (Wahdini, 2006).

Informasi Akuntansi pada UKM masih kurang diperhatikan oleh para pelaku UKM. Menurut Wahdini (2006), akuntansi keuangan pada UKM di Indonesia masih terbilang rendah dan memiliki banyak kelemahan. Kelemahan-kelemahan tersebut dikarenakan rendahnya pendidikan pelaku UKM, kurangnya pemahaman mengenai Standar Akuntansi Keuangan (SAK), dan masih belum adanya peraturan yang mewajibkan bisnis UKM untuk menyelenggarakan penyusunan laporan keuangan. Beberapa pelaku UKM belum melakukan pencatatan menurut kaidah akuntansi, sehinggga menyulitkan mereka mendapatkan pinjaman dari pihak luar perusahaan seperti pemerintah, calon investor dan perbankan akibat tidak jelasnya sistem akuntansi mereka. Ketidak jelasan tersebut disebabkan karena harus memerlukan waktu lama untuk mengumpulkan bukti transaksi yang menunjukkan bahwa usahanya layak untuk diberi pinjaman dengan mewawancarai pelaku 
UKM dan melihat langsung kondisi usahanya. Padahal Informasi akuntansi mempunyai peranan penting untuk mencapai keberhasilan usaha, termasuk bagi usaha kecil dan menengah (Magginson et al, 2009).

Pelaku UKM juga masih banyak yang belum melakukan pemisahaan asset antara asset usaha dan asset pribadi. Akibatnya pelaku UKM tidak mengetahui secara persis berapa pendapatan (kas) yang seharusnya diterima, berapa biaya operasi yang seharusnya dikeluarkan dan berapa yang seharusnya masih tersisa. Kalaupun ada perencanaan kegiatan, biasanya tidak tersusun secara rapi dan tertib serta hanya sebatas pengingat. Permasalahan itu semakin kompleks seiring dengan semakin besarnya kegiatan usaha UKM.

Ikatan Akuntan Indonesia (2009) telah menerbitkan Standar Akuntansi Keuangan untuk Entitas Tanpa Akuntabilitas Publik (SAKETAP) dengan tujuan untukmempermudah para pelaku UKM dalam menyusun laporan keuangan usaha mereka. Diterbitkannya SAK ETAP ini, diharapkan para pelaku UKM dapat menerapkannya dengan lebih mudah dan dapat memperoleh manfaat dari penyelenggaraan laporan keuangan tersebut.

Penyelenggaraan laporan keuangan ini memberikan manfaat yang cukup besar bagi perkembangan UKM yang diantaranya adalah pelaku UKM dapat lebih mudah untuk mengetahui bagaimana perkembangan usahanya karena laporan keuangan memberikan informasi mengenai posisi keuangan, kinerja keuangan, dan perubahan modal dari UKM tersebut, dengan adanya laporan keuangan pada UKM, maka akan membantu pelaku UKM dalam pengambilan keputusan mengenai usahanya di masa depan. Informasi yang terkandung dalam laporan keuangan akan menjadikan kegiatan-kegiatan operasional UKM lebih terstruktur sehingga dapat berjalan dengan lebih baik dan efisien.

Kondisi UKM di kecamatan Magetan khususnya di sentra batik tulis "Pring Sedapur" tidak jauh berbeda, mereka masih banyak mengalami kesulitan dalam mempraktekan akuntansi sesuai ketentuan yang telah ditetapkan oleh Ikatan Akuntan Indonesia berdasarkan Standar Akuntansi Keuangan-Entitas Tanpa Akuntabilitas Publik (SAK-ETAP), sehingga informasi akuntansi yang dihasilkan tidak memadai dan juga tidak akurat. Hal tersebut sebagai hambatan dalam mengembangkan bisnis terutama untuk mendapatkan tambahan modal eksternal. Padahal pangsa pasar batik"Pring Sedapur" ini masih sangat bagus karena seluruh satuan kerja di pemerintahan Kabupaten Magetan mengharuskan memakai batik khas daerah yaitu Pring Sedapur. Berdasarkan uraian di atas maka penulis tertarik untuk melakukan penelitian dengan judul :"Persepsi UKM terhadap laporan keuangan berdasarkan SAK ETAP"

\section{RUMUSAN MASALAH}

Penelitian ini mencoba mencari persepsi pelaku UKM terhadap pelaporan keuangan berdasarkan SAK ETAP, sehingga rumusan masalah dari penelitian ini adalah:

1. Bagaimana persepsi pelaku UKM tentang penerapan akuntansi?

2. Apakah pelaku UKM sudah menyusun Laporan Keuangan sesuai dengan SAK ETAP?

\section{TUJUAN PENELITIAN}

Tujuan dalam penelitian ini antara lain:

1. Menganalisis persepsi pelaku UKM tentang penerapan akuntansi 
2. Menganalisis kesesuaian pelaku UKM dalam menyusun Laporan Keuangan dengan SAK ETAP.

\section{KONTRIBUSI PENELITIAN}

Kontribusi dalam penelitian ini antara lain:

1. Kontribusi teori

Hasil penelitian ini memberikan kontribusi tentang penerapan akuntansi pelaku UKM berdasarkan SAK ETAP.

2. Kontribusi praktek

Hasil penelitian ini memberikan kontribusi secara praktis kepada pelaku UKM pengrajin batik "Pring Sedapur" didesa sidomukti kecamatan plaosan kabupaten magetan tentang penerapan penyusunan laporan keuangan berdasarkan SAK ETAP.

\section{TINJAUAN PUSTAKA}

\section{Pengertian Persepsi}

Manusia sebagai makhluk sosial yang sekaligus juga makhluk individual, maka terdapat perbedaan antara individu yang satu dengan yang lainnya, adanya perbedaan inilah yang antara lain menyebabkan mengapa seseorang menyenangi suatu obyek sedangkan orang lain tidak senang bahkan membenci obyek tersebut. Hal ini sangat tergantung bagaimana individu menanggapi obyek tersebut dengan persepsinya. Tingkah laku dan penyesuaian ditentukan oleh persepsinya. Persepsi pada hakikatnya adalah merupakan proses penilain seseorang terhadap objek tertentu.

Menurut Kamus Besar Bahasa Indonesia (2008:674) persepsi diartikan sebagai tanggapan (penerimaan) langsung dari sesuatu atau merupakan proses seseorang mengetahui bebarapa hal melalui panca inderanya.

Menurut Ikhsan dan Ishak (2005:57) persepsi adalah bagaimana orang melihat atau menginterpretasikan peristiwa, objek, serta manusia. Mangkunegara (dalam Arindita, 2000) berpendapat bahwa persepsi adalah proses pemberian arti atau makna terhadap lingkungan. Dalam hal ini persepsi mencangkup penafsiran obyek, penerimaan stimulis (input), pengorganisasian stimulus, dan pemberian penafsiran terhadap stimulus yang telah diorganisasikan dengan cara mempengaruhi prilaku dan perubahan sikap.

\section{Faktor Yang Mempengaruhi Persepsi}

Menurut Robbins (2003) persepsi pada umumnya dipengaruhi oleh dua faktor, yaitu faktor internal dan faktor ekstenal. Faktor internal berasal dari dalam diri individu misalnya sikap, kebiasaan dan kemauan. Sedangkan faktor eksternal adalah faktor yang berasal dari luar individu. Dijelaskan oleh Robbins (2003) bahwa meskipun individu-individu memandang pada satu benda yang sama, mereka dapat mempersepsikannya berbeda. Hal ini dipengaruhi oleh:

1. Pelaku persepsi

Apabila seorang individu memandang suatu obyek dan mencoba menafsirkan apa yang dilihatnya, 
penafsiran itu sangat dipengaruhi oleh karakteristik pribadi dari pelaku persepsi individu itu, seperti sikap, motif, kepentingan, minat, pengalaman dan harapan.

2. Obyek atau yang dipersepsikan

Karakteristik dari target yang akan diamati dapat mempengaruhi apa yang dipersepsikan, sasaran itu mungkin berupa orang, benda atau peristiwa.

3. Keadaan dimana persepsi itu dilakukan.

Unsur lingkungan atau situasi yang terjadi saat seseorang menilai suatu obyek.

\section{Definisi Usaha Kecil dan Menengah}

Menurut Undang-Undang No 20 Tahun 2008 ini, yang disebut dengan usaha kecil adalah entitas yang memiliki kriteria sebagai berikut:

1. Kekayaan bersih lebih dari Rp 50.000.000,00 (lima puluh juta rupiah) sampai dengan paling banyak Rp 500.000.000,00 (lima ratus juta rupiah) tidak termasuk tanah dan bangunan tempat usaha; dan

2. Memiliki hasil penjualan tahunan lebih dari Rp $300.000 .000,00$ (tiga ratus juta rupiah) sampai dengan paling banyak Rp 2.500.000.000,00 (dua milyar lima ratus juta rupiah).

Usaha Menengah adalah entitas usaha yang memiliki kriteria sebagai berikut:

1. Kekayaan bersih lebih dari Rp 500.000.000,00 (lima ratus juta rupiah) sampai dengan paling banyak Rp 10.000.000.000,00 (sepuluh milyar rupiah) tidak termasuk tanah dan bangunan tempat usaha; dan

2. Memiliki hasil penjualan tahunan lebih dari Rp2.500.000.000,00 (dua milyar lima ratus juta rupiah) sampai dengan paling banyak Rp 50.000.000.000,00 (lima puluh milyar rupiah).

\section{Standar Akuntansi Keuangan Entitas Tanpa Akuntabilitas Publik (SAK-ETAP)}

Standar Akuntansi Keuangan untuk Entitas Tanpa Akuntabilitas Publik (SAK ETAP) dimaksudkan untuk digunakan entitas tanpa akuntabilitas publik. Entitas tanpa akuntabilitas publik adalah entitas yang:

1. Tidak memiliki akuntabilitas publik yang signifikan; dan

2. Menerbitkan laporan keuangan untuk tujuan umum (General Purpose Financial Statement) bagi pengguna eksternal. Contoh pengguna eksternal adalah pemilik yang tidak terlibat langsung dalam pengelolaan usaha, kreditur, dan lembaga pemeringkat kredit.

Suatu entitas dikatakan memiliki akuntabilitas publik signifikan jika:

1. Entitas telah mengajukan pernyataan pendaftaran, atau dalam proses pengajuan pernyataan pendaftaran, pada otoritas pasar modal atau regulator lain untuk tujuan penerbitan efek di pasar modal; atau

2. Entitas menguasai aset dalam kapasitas sebagai fidusia untuk sekelompok besar masyarakat, seperti bank, entitas asuransi, pialang dan atau pedagang efek, dana pensiun, reksa dana, dan bank investasi.

Pernyataan diatas jelas mengandung makna bahwa entitas kecil dan menengah yang dimaksud oleh SAK ETAP adalah entitas kecil menengah non- listed atau entitas yang tidak masuk dalam bursa saham. Artinya ada dua standar akuntansi yang berbeda yang dijadikan acuan dalam penyusunan dan pelaporan keuangan. 
Ini berarti juga akan ada standar pengukuran dan pengungkapan yang berbeda dari masing-masing standar akuntansi tersebut. Di satu sisi ada SAK ETAP yang khusus ditujukan untuk entitas kecil menengah yang nonlisted, di sisi lain ada SAK umum, dalam hal ini PSAK yang ditujukan untuk entitas lainnya, termasuk entitas kecil menengah jika entitas tersebut termasuk listed company. Laporan keuangan yang dihasilkan oleh suatu entitas nantinya harus menyebutkan bahwa laporan keuangan tersebut telah dinyatakan sesuai dengan standar akuntansi yang digunakan, apakah SAK ETAP atau PSAK.

SAK ETAP diterapkan untuk penyusunan laporan keuangan yang dimulai pada atau setelah 1 Januari 2011. Penerapan dini diperkenankan. Jika SAK ETAP diterapkan dini, maka entitas harus menerapkan SAK ETAP untuk penyusunan laporan keuangan yang dimulai pada atau setelah 1 Januari 2010 (SAK ETAP 2009:166).

\section{Karakteristik Kualitatif Informasi dalam Laporan Keuangan}

Tujuan dari laporan keuangan SAK ETAP itu sendiri adalah menyediakan informasi mengenai posisi keuangan, kinerja, dan laporan arus kas suatu entitas yang bermanfaat bagi sejumlah besar pengguna dalam pengambilan keputusan ekonomi oleh siapapun yang tidak dalam posisi dapat meminta laporan keuangan khusus untuk memenuhi informasi tertentu. Laporan keuangan juga menunjukkan apa yang telah dilakukan manajemen (stewardship) atau pertanggungjawaban manajemen atas sumberdaya yang dipercayakan kepadanya.

Menurut Soemarso (2004) Salah satu ciri khas yang membuat informasi dalam laporan keuangan berguna bagi penggunanya adalah karakteristik kualitatif, yaitu:

1. Dapat dipahami (Understandability)

2. Relevan (Relevance)

3. Materialitas (Materiality)

4. Keandalan (Reliability)

5. Substansi mengungguli bentuk (Subtance Over Form)

6. Pertimbangan Sehat (Prudence)

7. Kelengkapan (Completeness)

8. Dapat dibandingkan (Comparability)

9. Tepat waktu (Timeliness)

10. Keseimbangan antara biaya dan manfaat (Balance Between Benefit And Cost)

\section{Penyajian Laporan Keuangan}

Penyajian laporan keuangan dalam SAK ETAP tidak berbeda dengan sebagaimana yang diatur dalam PSAK 1: Penyajian laporan keuangan, dimana secara substansi pengaturan tersebut merupakan ringkasan dari PSAK yang juga mencakup pengaturan mengenai komponen laporan keuangan. Perbedaan yang paling mendasar adalah, dalam SAK ETAP, entitas yang menggunakan standar ini harus mengungkapkan pernyataan bahwa entitas patuh secara keseluruhan terhadap SAK ETAP ini dalam catatan atas laporan keuangannya. Hal lain terkait dengan pengaturan mengenai penyajian laporan keuangan ini adalah kelangsungan usaha, frekuensi 
pelaporan, konsistensi penyajian, informasi komparatif, materialitas, agregasi dan komponen lengkap laporan keuangan. Posisi dan kinerja keuangan yang ada dalam SAK ETAP secara umum tidak berbeda dengan yang ada dalam PSAK, yaitu aset, kewajiban, ekuitas, penghasilan dan beban. Dalam SAK ETAP, ada beberapa perbedaan yang signifikan dengan PSAK yaitu :

1. Tidak diperkenankannya adanya "pos luar biasa"

2. Diperkenankannya untuk menggabungkan laporan laba rugi dan laporan perubahan jika memenuhi kondisi tertentu, yaitu perubahan ekuitas yang hanya berasal dari :
a. Laba Rugi periode berjalan
b. Pembayaran dividen
c. Koreksi kesalahan periode sebelumnya
d. Perubahan kebijakan akuntansi

Posisi keuangan suatu entitas terdiri dari aset, kewajiban, dan ekuitas pada suatu waktu tertentu. Unsur laporan keuangan yang berkaitan secara langsung dengan pengukuran posisi keuangan adalah aset, kewajiban, dan ekuitas. Unsur-unsur ini didefinisikan sebagai berikut:
a. Aset adalah sumber daya yang dikuasai entitas sebagai akibat dari peristiwa masa lalu dan dari mana manfaat ekonomi di masa depan diharapkan akan diperoleh entitas.
b. Kewajiban merupakan kewajiban masa kini entitas yang timbul dari peristiwa masa lalu, yang penyelesaiannya diharapkan mengakibatkan arus keluar dari sumber daya entitas yang mengandung manfaat ekonomi.
c. Ekuitas adalah hak residual atas aset entitas setelah dikurangi semua kewajiban.

\section{METODE PENELITIAN}

\section{Jenis Penelitian}

Jenis penelitian yang dilakukan adalah penelitian deskriptif dengan pendekatan kualitatif. Menurut Sugiyono (2010: 15) penelitian kualitatif adalah penelitian yang berlandaskan pada filsafat postpositivisme, digunakan untuk meneliti pada kondisi obyek yang alamiah. Penelitian deskriptif merupakan penelitian yang melakukan pengumpulan data untuk menggambarkan dan memberi penjelasan yang lebih mendetail mengenai fenomena dari subjek penelitian.

\section{Obyek Penelitian}

\section{Obyek Penelitian}

Obyek penelitian merupakan variabel yang akan diteliti. Pada penelitian ini obyeknya adalah persepsi pelaku UKM dalam menyusun laporan keuangan.

\section{Tempat Penelitian}

Penelitian ini dilakukan pada pengusaha UKM pengrajin batik tulis "Pring Sedapur" di Desa Sidomukti Kecamatan Plaosan Kabupaten Magetan. 
Waktu Penelitian

Penelitian ini dilaksanakan dalam kurun waktu enam bulan terhitung mulai bulan Februari 2018.

\section{Populasi Dan Sampel Penelitian}

Populasi adalah wilayah generalisasi yang terdiri atas obyek atau subyek yang mempunyai kualitas dan karakteristik tertentu yang ditetapkan oleh peneliti untuk dipelajari dan ditarik kesimpulannya (Sugiyono, 2010:117). Populasi dalam penelitian ini adalah pelaku UKM pengrajin batik tulis "Pring Sedapur" di Desa Sidomukti Kecamatan Plaosan Kabupaten Magetan. Pengambilan sampel dalam penelitian ini ditentukan dengan menggunakan tekhnik snowbaal yaitu, teknik pengambilan sampel sumber data, yang pada awalnya jumlahnya sedikit, lama-lama menjadi besar (Sugiyono,2010). Sampel dalam penelitian ini sebanyak 3 UKM pengrajin batik tulis "Pring Sedapur" di Desa Sidomukti Kecamatan Plaosan Kabupaten Magetan.

\section{Teknik Pengumpulan Data}

Pengumpulan data yang digunakan dalam penelitian ini adalah natural setting (kondisi yang alamiah), sumber data primer, dan teknik pengumpulan data lebih banyak pada observasi partisipatif, wawancara mendalam dan dokumentasi. Menurut sugiyono (2010:310) pengumpulan data dengan observasi partisipatif adalah peneliti terlibat dengan kegiatan sehari-hari orang yang sedang diamati atau yang akan digunakan sebagai sumber data penelitian, maka data yang diperoleh akan lebih lengkap, tajam, dan sampai mengetahui pada tingkat makna dari setiap perilaku yang tampak. Wawancara adalah pertemuan dua orang untuk bertukar informasi dan ide melalui tanya jawab, sehingga dapat dikontruksikan makna dalam suatu topik tertentu. Dokumen merupakan catatan peristiwa yang sudah berlalu, bisa berbentuk tulisan, gambar, atau karya-karya monumental dari seseorang.

\section{Teknik Analisis Data}

Analisis yang digunakan dalam penelitian ini menggunakan analisis deskriptif. Tujuan analisis deskriptif yaitu untuk memberikan gambaran mengenai hasil penelitian secara umum profil responden, sikap wirausaha dan peningkatan usaha dipandang dari sudut responden dalam melihat tentang Penerapan Akuntansi bagi UKM berdasarkan SAK ETAP. Penelitian ini menggunakan pendekatan deskriptif dengan melakukan wawancara mendalam kepada para pelaku UKM, dari hasil wawancara tersebut kemudian penulis menganalisis hasil wawancara para pelaku UKM untuk melihat bagaimana persepsi pelaku UKM.

\section{HASIL DAN PEMBAHASAN}

\section{Deskriptif objek penelitian}

Asal mula Batik tulis motif "Pring Sedapur" berasal dari desa Sidomukti dukuh Papringan, maka dari itu di desa Sidomukti banyak berdiri usaha kecil batik tulis yang bermotif pring sedapur. Adapun deskriptif dari setiap usaha tersebut adalah sebagai berikut:

PERSEPSI PELAKU UKM TERHADAP LAPORAN KEUANGAN BERDASARKAN 


\section{UKM Batik KUBE Mukti Rahayu}

KUBE Mukti Rahayu merupakan kelompok usaha bersama yang berdiri sejak tahun 2002. Anggota KUBE terdiri dari para ibu rumah tangga, baik muda maupun tua yang masih produktif yang dipimpin oleh ibu Siswati. Awalnya anggota kelompok terdiri dari 10 orang dan kini anggota kelompok sudah mencapai 34 orang. KUBE Mukti Rahayu berlokasi di Dusun Papringan Desa Sidomukti Kecamatan Plaosan Kabupaten Magetan. Lokasi ini berada di pedesaan, walaupun begitu lokasi ini cukup terkenal bagi warga/ calon pembeli. Akses menuju lokasi ini juga mudah dicapai. Dalam pendirian KUBE ini mendapat dukungan dari pemerintah berupa pelatihan keterampilan membatik dan juga berupa peralatan membatik. Anggota KUBE tidak mengeluarkan modal sama sekali. Dalam proses berdirinya dulu anggota tidak mendapat upah atas pekerjaannya. Mulai mendapat upah pada tahun 2004.

Seiring dengan berkembangnya usaha bersama ini, KUBE Mukti Rahayu telah memiliki lebih dari 25 motif, dan kini motif-motif tersebut sedang dalam proses pengurusan hak cipta. Motif batik ini terkenal dengan nama motif batik pring sedapur. Dimana motif batik di dominasi dengan gambar pring (dalam bahasa Indonesia: Bambu). Motif yang dihadirkan tidak monoton, terdapat kombinasi motif batik dengan gambar-gambar lain seperti hewan, bunga, batu, dan alam. Selain memproduksi batik tulis, KUBE Mukti Rahayu juga memproduksi batik cap atau sering di sebut dengan batik sony. Dimana produksi batik cap ini tidak dilakukan di KUBE Mukti Rahayu akan tetapi KUBE Mukti Rahayu menjalin kerjasama dengan pelaku usaha batik lainnya. Hasil kerja keras ibu-ibu ini pun tidak sia-sia. Terbukti pada tahun 2013 KUBE Mukti Rahayu memperoleh juara 2 tingkat provinsi dalam kegiatan lomba Kelompok Usaha Bersama.

\section{UKM Batik KUBE Mukti Lestari}

UKM Batik Mukti Lestari dibentuk oleh Kepala Desa, Bapak Tikno pada Maret 2006. UKM ini merupakan pengembangan dari UKM Batik Mukti Rahayu yang merupakan perintis awal UKM batik di Desa Sidomukti. UKM Batik Mukti Lestari yang berlokasi di Jl. Mukti Graha No. 03, Desa Sidomukti, tepatnya di Balai Desa Sidomukti, Plaosan, Magetan. Pada tahun 2009 UKM Batik Mukti Lestari melakukan restrukturisasi menjadi tiga KUBE (Kelompok Usaha Bersama). Meskipun dipecah menjadi tiga KUBE namun sistem baik pembelian bahan baku, produksi dan pemasaran tetap dalam satu UKM. Namun untuk pengelolaan keuangan dibagi pada masing masing KUBE.

\section{UKM Batik Seruling Etan}

UKM Batik Seruling Etan berdiri pada tahun 2014. Setelah bapak Sutikno tidak lagi menjabat sebagai kepala desa, beliau mendirikan sendiri usaha batik tulis yang bernama Seruling Etan di dusun Kalitengah desa Sidomukti kecamatan Plaosan. Tenaga kerja yang terlibat dalam pembuatan batik tersebut adalah ibu-ibu warga setempat sebanyak 20 orang. Mereka bekerja setiap hari dan sistem gaji secara harian serta kalau ada lemburan maka akan ditambah upah lembur. Mereka mengerjakan berdasarkan pesanan pelanggan. Batik yang dihasilkan dengan ciri has utama motif gambar pring atau dalam bahasa Indonesia disebut bambu. Pemasaran batik ini sudah sampai luar jawa, yaitu mulai daerah Magetan dan sekitarnya, Jakarta dan Kalimantan. 


\section{Karakteristik responden}

Karakteristik reponden dilihat dari tingkat pendidikan diperoleh data sebagai berikut: Berdasarkan tabel 1 diatas menunjukkan bahwa responden memiliki tingkat pendidikan SLTA sebesar $66,67 \%$ atau 2 orang dan responden yang memiliki tingkat pendidikan perguruan tinggi sebesar 33,33\% atau 1 orang.

Karakteristik reponden dilihat dari tingkat usia diperoleh data sebagai berikut: Berdasarkan tabel 2 diatas menunjukkan bahwa semua responden memiliki tingkat usia lebih dari 50 tahun sebesar 100\%.

Karakteristik reponden dilihat dari lama membuka usaha diperoleh data sebagai berikut: Berdasarkan tabel 3 diatas menunjukkan bahwa semua responden memiliki pengalaman lama membuka usaha yang berbeda yaitu 5-10 tahun sebanyak 33,33\%, 11-15 tahun sebanyak 33,33\%, dan 16-20 tahun sebanyak 33,33\%.

\section{Deskriptif Penelitian}

Penelitian ini dilakukan untuk mengetahui bagaimana persepi pelaku UKM tentang penerapan akuntansi berdasarkan SAK ETAP. Informasi yang dibutuhkan dalam penelitian ini merupakan data yang diperoleh dari hasil wawancara terstruktur yaitu berupa pertanyaan yang digunakan untuk mendeskripsikan persepsi para pelaku UKM dan penelitian ini termasuk dalam jenis penelitian deskriptif yang bertujuan hanya untuk sebatas membuat deskripsi yang tepat, apa adanya tentang fakta-fakta dan sifat-sifat objek tanpa membuat prediksi atau mencari pemecahan atas masalah yang ada dalam objek tersebut. Penelitian ini adalah tentang Persepsi Pelaku UKM Tentang Penerapan Akuntansi berdasarkan SAK ETAP pada UKM pengrajin batik tulis "Pring Sedapur" di Desa Sidomukti Kecamatan Plaosan Kabupaten Magetan.

Analisa Jawaban Persepsi Pelaku UKM Tentang Penerapan Akuntansi. Pertanyaan: Berapa omset perbulan para pelaku UKM? Berdasarkan tabel 4 diatas menunjukkan bahwa 100\% para pelaku UKM omset per bulan sebesar Rp. 25.000.000- Rp.50.000.000. Menurut Undang-Undang No 20 Tahun 2008, omset yang dimiliki pelaku UKM menunjukkan usaha tersebut masih tergolong usaha kecil.

Pertanyaan: Apakah para pelaku UKM mengumpulkan bukti transaksi? Berdasarkan tabel 5 diatas menunjukkan bahwa para pelaku UKM dalam mengumpulkan bukti transaksi menyatakan 100\% menjawab YA dan yang menyatakan tidak 0\%. Argumen para pelaku UKM dalam hal ini mengatakan bahwa mengumpulkan bukti transaksi sangat penting dalam menjalankan usahanya, meskipun bukti transaksi tersebut sebatas dikumpulkan saja dan tidak tertata rapi. Alasan utama mereka yaitu untuk mengetahui harga ecer produk, tanda bukti supir/kernet dari perusahaan sebagai distributor telah mengantarkan barang sesuai dengan pesanan, dan untuk tanda bukti bahwa transaksi ini dilakukan secara cash atau kredit.

Pertanyaan: Apakah para pelaku UKM membuat catatan usaha? Berdasarkan tabel 6 menunjukkan bahwa para pelaku UKM dalam membuat catatan usaha menyatakan $100 \%$ menjawab YA dan yang menyatakan tidak $0 \%$. Argumen para pelaku UKM dalam hal ini mengatakan bahwa catatan usaha ini penting dilakukan sebagai pengingat berbagai peristiwa yang telah terjadi, meskipun tidak dicatat secara rapi, teratur dan tidak sesuai dengan standar akuntansi.

Pertanyaan: Apakah para pelaku UKM membuat pencatatan usaha dalam bentukjurnal? Berdasarkan tabel 7 menunjukkan bahwa para pelaku UKM dalam membuat catatan usaha dalam bentuk jurnal menyatakan 0\% 
menjawab YA dan yang menyatakan tidak 100\%. Argumen para pelaku UKM dalam hal ini mengatakan bahwa mereka hanya mencatat berbagai peristiwa saja tetapi tidak dibuat dalam bentuk jurnal dengan alasan mereka tidak mengerti bagaimana proses pembuatan jurnal, merasa ribet, tidak ada waktu untuk mempelajarinya dan keterbatasan sumber daya manusia.

Pertanyaan: Apakah para pelaku UKM membuat buku besar? Berdasarkan tabel 8 menunjukkan bahwa para pelaku UKM dalam membuat buku besar menyatakan 0\% menjawab YA dan yang menyatakan tidak 100\%. Argumen para pelaku UKM dalam hal ini mengatakan bahwa mereka tidak tahu buku besar itu seperti apa sehingga tidak membuatnya. Mereka hanya membuat buku penerimaan dan pengeluaran kas saja.

Pertanyaan: Apakah para pelaku UKM memiliki kemampuan dasar akuntansi? Berdasarkan tabel 9 menunjukkan bahwa para pelaku UKM memiliki kemampuan dasar akuntansi menyatakan 0\% menjawab YA dan yang menyatakan tidak 100\%. Argumen para pelaku UKM dalam hal ini mengatakan bahwa latar belakang pendidikan mereka semua adalah SLTA dan mereka tidak punya kemampuan dasar akuntansi. Kemampuan para pelaku UKM mayoritas hanya melakukan pencatatan arus kas masuk dan keluar.

Pertanyaan: Apakah para pelaku UKM memiliki bagian keuangan? Berdasarkan tabel 10 menunjukkan bahwa para pelaku UKM memiliki bagian keuangan menyatakan 100\% menjawab YA dan yang menyatakan tidak 0\%. Argumen para pelaku UKM dalam hal ini mengatakan bahwa mereka memiliki bagian keuangan yang bertugas mencatat keluar masuknya uang usaha. Bagian keuangan ini di pegang oleh salah satu karyawan yang disebut bendahara.

Pertanyaan: Apakah para pelaku UKM membuat laporan keuangan? Berdasarkan tabel 11 menunjukkan bahwa para pelaku UKM dalam membuat laporan keuangan menyatakan 0\% menjawab YA dan yang menyatakan tidak $100 \%$. Argumen para pelaku UKM dalam hal ini mengatakan bahwa mereka sama sekali tidak tahu bagaimana proses membuat laporan keuangan dan menganggap hal tersebut rumit, susah untuk dipelajari dan keterbatasan informasi tentang manfaat laporan keuangan.

Pertanyaan: Apakah para pelaku UKM membedakan kepentingan usaha dan pribadi? Berdasarkan tabel 12 menunjukkan bahwa para pelaku UKM dalam membedakan kepentingan usaha dan pribadi menyatakan $67 \%$ menjawab YA dan yang menyatakan tidak 33\%. Argumen para pelaku UKM yang menjawab YA dalam hal ini mengatakan bahwa mereka selalu membedakan kepentingan pribadinya dengan usahanya dikarenakan bentuk usaha KUBE selalu mendapat binaan dari Disperindag, sedangkan yang menjawab TIDAK keuangan usaha masih dicampur jadi satu dengan keuangan pribadi. Mereka masih bingung untuk memisah berbagai kepentingan dan keuangan antara usaha dan pribadi.

Apakah para pelaku UKM memiliki catatan aktiva/harta? Berdasarkan tabel 13 menunjukkan bahwa para pelaku UKM dalam memiliki catatan aktiva/harta menyatakan 100\% menjawab YA dan yang menyatakan tidak 0\%. Argumen para pelaku UKM dalam hal ini mengatakan bahwa mereka mencatat harta apa saja yang dimiliki, kecuali tanah dan bangunan. Mereka hanya punya hak pakai, bukan beli ataupun sewa.

Apakah para pelaku UKM menyusun laporan keuangan berdasarkan SAK ETAP? Berdasarkan tabel 14 menunjukkan bahwa para pelaku UKM dalam menyusun laporan keuangan berdasarkan SAK ETAP menyatakan $0 \%$ menjawab YA dan yang menyatakan tidak 100\%. Argumen para pelaku UKM dalam hal ini 
mengatakan bahwa mereka tidak pernah mendengar tentang SAK ETAP, tidak tahu bentuk dan aturannya, bahkan mereka tidak pernah meyusun laporan keuangan. Mereka belum pernah mendapatkan informasi bagaimana menyusun laporan keuangan berdasarkan SAK ETAP.

\section{Pembahasan}

Berdasarkan hasil analisis diatas dapat dijelaskan bahwa faktor usia, tingkat pendidikan dan pengalaman usaha tidak menunjukkan adanya perbedaan pendapat tentang persepsi mereka tentang penerapan akuntansi hal ini bisa dilihat dari hasil jawaban para responden. Ketiga pelaku UKM tersebut masih tergolong usaha kecil yang memiliki kekayaan bersih lebih dari Rp 50.000.000,00 (lima puluh juta rupiah) sampai dengan paling banyak Rp 500.000.000,00 (lima ratus juta rupiah) tidak termasuk tanah dan bangunan tempat usaha. Para pelaku UKM rata-rata sudah memiliki bagian keuangan tersendiri dalam usahanya yang disebut sebagai bendahara. Mereka bertugas mengumpulkan transaksi, membuat catatan usaha, pemisahan aktiva dan mencatat penerimaan dan pengeluarn kas saja. Meskipun pencatatan tersebut masih sederhana dan belum sesuai dengan standar akuntansi.

Pelaku UKM tersebut belum membuat jurnal, buku besar dan menyusun laporan keuangan. Latar pendidikan yang mayoritas SLTA dan kurang informasi tentang penerapan akuntansi membuat ketiga KUBE tersebut belum menyusun laporan keuangan sesuai SAK ETAP. Pelaku UKM lebih mengutamakan pengalaman dalam menjalankan usahanya dibandingkan harus belajar akuntansi. Pengalaman dalam hal ini pelaku UKM sudah terbiasa dengan kegiatan mereka yang berjalan apa adanya. Mereka sulit menyisihkan waktu untuk mempelajari akuntansi dan merasa tidak ada dampak dan manfaat secara jelas dari mempelajari akuntansi dan menyusun laporan keuangan. Bila dikaitkan dengan teori Akuntansi bagi UKM, Akuntansi memberikan informasi mengenai aktivitas ekonomi dan kondisi UKM kepada pemilik dan pihak-pihak yang berkepentingan seharusnya para pelaku UKM menerapkan akuntansi walaupun secara sederhana.

Para pelaku UKM sebenarnya sering mendapat pelatihan dan bimbingan dari Disperindag, tetapi hal tersebut terfokus pada inovasi motif batik dan proses pemasarannya. Mereka belum mendapat pelatihan secara khusus tentang pengelolaan keuangan. Hal tersebut berakibat pengelolaan keuangan masih sederhana, belum lengkap bahkan tidak sesuai dengan SAK ETAP.

\section{KESIMPULAN DAN SARAN}

\section{Kesimpulan}

Berdasarkan pembahasan diatas dapat diambil kesimpulan sebagai berikut:

1. Faktor usia, pendidikan dan lama membuka usaha/pengalaman tidak menunjukkan adanya perbedaan pendapat tentang persepsi mereka tentang penerapan akuntansi hal ini bisa dilihat dari hasil jawaban para responden.

2. Para pelaku UKM sudah membuat catatan akuntansi meskipun masih sangat sederhana. Mereka belum membuat jurnal, buku besar dan menyusun laporan keuangan sesuai dengan SAK ETAP, karena keterbatasan pengetahuan dan informasi bagaimana penerapan akuntansi sesuai dengan SAK ETAP.

PERSEPSI PELAKU UKM TERHADAP LAPORAN KEUANGAN BERDASARKAN 


\section{Saran}

Berdasarkan hasil pembahasan, maka saran dari peneliti adalah sebagai berikut:

1. Pelaku UKM sebaiknya selalu membuat catatan usahanya dimulai dari pengumpulan bukti transaksi, membuat jurnal, buku besar sampai menyusun laporan keuangan meskipun masih sederhana supaya dapat diketahui secara umum bagaimana perkembangan usahanya.

2. Perlu adanya peningkatan SDM terutama dibagian keuangan dengan mengikuti berbagai pelatihan supaya pengelolaan keuangan bisa lebih jelas, terperinci, lengkap dan sesuai dengan SAK ETAP.

3. Bagi Disperindag, sebaiknya pembinaan dan pelatihan untuk UKM Batik tersebut tidak hanya terfokus pada inovasi produk dan pemasaran saja, tetapi perlu ada pelatihan tentang pengelolaan keuangan yang baik dan benar susuai dengan SAK ETAP.

Jurnal Akuntansi Indonesia 


\section{DAFTAR PUSTAKA}

Arindita, S. 2003. Hubungan antara Persepsi Kualitas Pelayanan dan Citra Bank dengan Loyalitas Nasabah. Skripsi (tidak diterbitkan). Surakarta: Fakultas Psikologi UMS.

Dewan Standar Akuntansi Keuangan. 2009. Standar Akuntansi Keuangan Entitas Tanpa Akuntabilitas Publik. Ikatan Akuntan Indonesia, Jakarta.

Ikhsan, Arfa dan Muhammad Ishak. 2005. Akuntansi Keprilakuan. Salemba Empat, Jakarta.

Megginson, W.L., M.J. Byrd, and L.C. Megginson. 2000. Small Business Management: An Entrepreneur's Guidebook. Third Ed. Irwin McGraw-Hill. Boston.

Robbins, Stephen P. 2003. Prinsip-Prinsip Perilaku Keorganisasian. Erlangga, Jakarta.

Soemarso. 2004. Akuntansi Suatu Pengantar Edisi Lima Revisi. Salemba Empat, Jakarta.

Sugiyono. (2010). Metode Penelitian Pendidikan. Bandung: Alfabeta.

Tim Penyusun Kamus Pusat Pembinaan dan Pengembangan Bahasa. 1999. Kamus Besar Bahasa Indonesia Edisi Kedua, Departemen Pendidikan dan Kebudayaan. Balai Pustaka, Jakarta.

Undang-Undang No 20 Tahun 2008.

Wahdini \& Suhairi. 2006. Persepsi Akuntan terhadap Overload Standar Akuntansi Keuangan (SAK) bagi UKM. Simposium Nasiaonal Akuntansi IX Padang. 


\section{LAMPIRAN}

Tabel 1. Karakteristik reponden berdasarkan tingkat pendidikan

\begin{tabular}{ccc}
\hline Pendidikan & Jumlah (orang) & $\begin{array}{c}\text { Prosentse } \\
\text { (\%) }\end{array}$ \\
\hline Tidak sekolah & 0 & 0 \\
\hline SD & 0 & 0 \\
\hline SMP & 0 & 0 \\
\hline SLTA & 2 & 66,67 \\
\hline Akademi/ perguruan tinggi & 1 & 33,33 \\
\hline TOTAL & 3 & $100 \%$
\end{tabular}

Sumber: Hasil penelitian, 2018 (data diolah)

Tabel 2. Karakteristik reponden berdasarkan tingkat usia

\begin{tabular}{ccc}
\hline Usia (tahun) & Jumlah (orang) & $\begin{array}{c}\text { Prosentse } \\
\text { (\%) }\end{array}$ \\
\hline$<20$ & 0 & 0 \\
\hline $21-30$ & 0 & 0 \\
\hline $30-40$ & 0 & 0 \\
\hline $41-50$ & 0 & 100 \\
\hline$>50$ & 3 & $100 \%$ \\
\hline TOTAL & 3 & 0 \\
\hline
\end{tabular}

Sumber: Hasil penelitian, 2018 (data diolah)

Tabel 3. Karakteristik reponden berdasarkan lama membuka usaha

\begin{tabular}{ccc}
\hline Tahun & Jumlah (orang) & Prosentse (\%) \\
\hline $5-10$ & 1 & 33,33 \\
\hline $11-15$ & 1 & 33,33 \\
\hline $16-20$ & 1 & 33,33 \\
\hline $21-25$ & 0 & 0 \\
\hline$>25$ & 0 & 0 \\
\hline TOTAL & 3 & $100 \%$
\end{tabular}

Sumber: Hasil penelitian, 2018 (data diolah) 
Tabel 4. Omset perbulan para pelaku UKM

\begin{tabular}{cl}
\hline Kriteria & Prosentase (\%) \\
\hline Rp. 10.000 .000 & 0 \\
\hline Rp. 15.000 .000 & 0 \\
\hline Rp. 20.000 .000 & 0 \\
\hline Rp. $25.000 .000-$ Rp. 50.000 .000 & 100 \\
\hline
\end{tabular}

Sumber: Hasil penelitian, 2018 (data diolah)

Tabel 5. Mengumpulkan bukti transaksi

\begin{tabular}{cc}
\hline Kriteria & Prosentase (\%) \\
\hline YA & 100 \\
\hline TIDAK & 0 \\
\hline
\end{tabular}

Sumber: Hasil penelitian, 2018 (data diolah)

Tabel 6. Membuat catatan usaha

\begin{tabular}{cc}
\hline Kriteria & Prosentase (\%) \\
\hline YA & 100 \\
\hline TIDAK & 0 \\
\hline
\end{tabular}

Sumber: Hasil penelitian, 2018 (data diolah)

Tabel 7. Pencatatan usaha dalam bentuk jurnal

\begin{tabular}{cc}
\hline Kriteria & Prosentase (\%) \\
\hline YA & 0 \\
\hline TIDAK & 100 \\
\hline
\end{tabular}

Sumber: Hasil penelitian, 2018 (data diolah) 
JURNAL AKUNTANSI INDONESIA

Tabel 8. Membuat buku besar

\begin{tabular}{|c|c|}
\hline Kriteria & Prosentase (\%) \\
\hline YA & 0 \\
\hline TIDAK & 100 \\
\hline \multicolumn{2}{|c|}{ Sumber: Hasil penelitian, 2018 (data diolah) } \\
\hline \multicolumn{2}{|c|}{ Tabel 9. Memiliki kemampuan dasar akuntansi } \\
\hline Kriteria & Prosentase (\%) \\
\hline YA & 0 \\
\hline TIDAK & 100 \\
\hline
\end{tabular}

Sumber: Hasil penelitian, 2018 (data diolah)

Tabel 10. Memiliki bagian keuangan

\begin{tabular}{cc}
\hline Kriteria & Prosentase (\%) \\
\hline YA & 100 \\
\hline TIDAK & 0 \\
\hline
\end{tabular}

Sumber: Hasil penelitian, 2018 (data diolah)

Tabel 11. Membuat laporan keuangan

\begin{tabular}{cc}
\hline Kriteria & Prosentase (\%) \\
\hline YA & 0 \\
\hline TIDAK & 100 \\
\hline
\end{tabular}

Sumber: Hasil penelitian, 2018 (data diolah)

Tabel 12. Membedakan kepentingan usaha dan pribadi

\begin{tabular}{cc}
\hline Kriteria & Prosentase (\%) \\
\hline YA & 67 \\
\hline TIDAK & 33 \\
\hline
\end{tabular}

Sumber: Hasil penelitian, 2018 (data diolah) 
Tabel 13. Catatan aktiva/harta

\begin{tabular}{cc}
\hline Kriteria & Prosentase (\%) \\
\hline YA & 100 \\
\hline TIDAK & 0 \\
\hline
\end{tabular}

Sumber: Hasil penelitian, 2018 (data diolah)

Tabel 14. Kesesuaian laporan keuangan berdasarkan SAK ETAP

\begin{tabular}{cc}
\hline Kriteria & Prosentase (\%) \\
\hline YA & 0 \\
\hline TIDAK & 100 \\
\hline
\end{tabular}

Sumber: Hasil penelitian, 2018 (data diolah) 